\title{
Fast cooling of the trindade island: ZrFT and U-Th/He thermochronologY
}

\author{
PROF. PETER HACKSPACHER SR., PHD
}

Rio de Janeiro State University (UERJ)

Presenting Author: peter.hackspacher@unesp.br

Fast cooling of the trindade island: ZrFT and U-Th/He thermochronologY

PETER C. HACKSPACHER ${ }^{1,2}$, GUSTAVO S. PERES ${ }^{1}$, ANDERSON C. SANTOS ${ }^{2}$, DANIEL F. GODOY ${ }^{1}$, BRUNO V. SILVA $^{1}$

${ }^{1}$ São Paulo State University (UNESP), IGCE/DG, Campus Rio Claro: ${ }^{2}$ Rio de Janeiro State University (UERJ), Faculty of Geology*peter.hackspacher@unesp.br

The Trindade Island is made up of ultrabasic to intermediate alkaline rocks resulting from different volcanic events. The geological column comprises from the bottom to the top: i) Trindade Complex represented by pyroclastic deposits and subvolcanic bodies (domes, dikes, plugs); ii) Desejado Sequence, with spills of phonolites, phono-tephrites and nephelinites, interbedded with pyroclastic rocks; iii) Morro Vermelho Formation; iv) Valado Formation and v) Paredão Volcano, newer volcanogenic successions characterized by the abundance of melanephelinitic spills and pyroclastic deposits. We reconstruct the magmatic crystallization using the thermal history versus time association for the basal Trindade Complex which preserves excellent minerals and isotopic markers were used for $\mathrm{ZrFT}$ and $\mathrm{U}-\mathrm{Th} / \mathrm{He}$ thermochronology.

The $\mathrm{ZrFT}$ and U/Th-He methodology developed at the Chronometry and Chronology Center of DG/IGCE/UNESP in apatite proved to be adequate for the reconstruction of the thermal history of the volcanic rocks and consistent with the geological environment. The alkaline igneous rocks of the Trindade Complex, rich in apatite and poor in zircon, presented enough raw material for the method.

The $\mathrm{ZrFT}$ and $\mathrm{U}-\mathrm{Th} / \mathrm{He}$ models shows in the time $\mathrm{x}$ temperature graphic a fast cooling, almost immediate, between 3.9 and 3.0 Ma, by the Trindade Complex (Lower Pliocene to Lower Pleistocene) reaching room temperature. Considering the zircon and apatite closing temperature, we would therefore have the final crystallization of the magma of the Trindade Complex at this time. Hence, maintaining the surface conditions to the present day. Younger volcanic activity decreased from 2.5 Ma to around 1.6 Ma. Around 0.25 Ma, volcanism ceases completely. This fact reflects a lack of material removal, that is, a lack of erosion which was expected for these rocks in an oceanic environment confirmed by petrography. 